\title{
Green Warbler Phylloscopus nitidus ringed at Blåvand: molecular confirmation of a Danish first and European eighth vagrant record
}

\author{
Kaukasisk lundsångare Phylloscopus nitidus ringmärkt i Blåvand: Danmarks \\ första och Europas åttonde raritetsfynd bekräftas molekylärt
}

MARTIN STERVANDER, HENRIK KNUDSEN \& ANDREAS BRUUN KRISTENSEN

Abstract

\begin{abstract}
On 27 May 2015, a Green Warbler Phylloscopus nitidus was caught and ringed at Blåvand Bird Observatory, the westernmost point in Denmark. The species is challenging to identify on morphological basis alone, and the bird's identity was confirmed with phylogenetic analyses of mitochondrial DNA sequences. This constitutes the first record of Green Warbler in Denmark, the third record in Fennoscandia - following records on Öland, Sweden, on 29 May 2003, and Åland, Finland, on 20 May 2012 - and the eighth vagrant record in Europe outside the species' very restricted peripheral breeding range.
\end{abstract}

Martin Stervander, Molecular Ecology and Evolution Lab, Dept of Biology, Lund University, Ecology Building, SE-223 62 Lund, Sweden and Centre for Ecology and Evolution in Microbial Model Systems (EEMiS), Linnaeus University, SE-391 82 Kalmar. Present affiliation: Institute of Ecology and Evolution, Universiy of Oregon, Eugene, OR 97403-5289 USA, mste@uoregon.edu.

Henrik Knudsen, Biblioteksvej 17 B, Landet, DK-5700 Svendborg, Denmark.

Andreas Bruun Kristensen, Borups Allé 29, 1.th., DK2200 København N, Denmark.

Received 17 July 2017, Accepted 14 August 2017, Editor: Sören Svensson

\section{Introduction}

Green Warbler Phylloscopus nitidus breeds from northern Turkey eastwards to Iran, and winters in India and southeast Asia (del Hoyo et al. 2006). It reaches marginally into Europe in southern Russia and northern Georgia (del Hoyo et al. 2006). East of its breeding distribution the Greenish Warbler $P h$. trochiloides and the Two-barred Warbler Ph. plumbeitarsus display a continuous distribution along a broken ring around the Tibetan Plateau, with several discernible subspecies/populations (Irwin et al. 2001).

The relationship between Green Warbler, Greenish Warbler, and Two-barred Warbler is complex (Irwin et al. 2001) and the Green Warbler has traditionally been regarded as a subspecies of Greenish Warbler. It was raised to species status by the British Ornithologists' Union in 2008 (Knox et al. 2008, BOU 2009), and by the Clements Checklist of Birds of the World in 2009 (Clements et al. 2009), while the International Ornithological Union regarded it as a species already in its first edition (Gill \& Wright 2006). The Two-barred Warbler was given species status later (Gill \& Wright 2006, Clements et al. 2014).
Before this first Danish record of Green Warbler there were two records from Fennoscandia and another five from remaining Europe. Two new records were added in 2016, making the total until and including 2016 ten records outside the restricted European breeding range (Table 1). Furthermore, there are seven accepted records in Israel (Slack 2009, IRDC 2016).

\section{Description}

On Wednesday 27 May 2015, the daily standardized ringing at Blåvand Bird Observatory could not be done because of strong wind (NW $12 \mathrm{~m} / \mathrm{s}$ ) and rain. Around noon, the wind decreased to $5 \mathrm{~m} / \mathrm{s}$ the rain stopped, and the sun began to shine. Some of the mist nets were opened and after about one hour, one bird was caught. Surprisingly, this turned out to be a Greenish Warbler type. However, this bird clearly differed from the Greenish Warblers that are caught almost every year at Blåvand. The date was also quite early for Greenish Warbler at Blåvand, as most records of Greenish Warbler at Blåvand are from June. Because of the colouration, the bird was 
Table 1. European records outside the peripheral breeding grounds of Green Warbler Phylloscopus nitidus.

Europeiska fynd utanför det perifera häckningsområdet av kaukasisk lundsångare Phylloscopus nitidus.

*Treatment/decision by national rarities committee. Behandling/beslut av nationell raritetskommitté.

**Another record, made 2000-09-27 in Greece, was listed by Hudson (2010), but this has been rejected by the Hellenic Rarities Committee (Nikos Probonas in litt.). Ytterligare ett fynd i Grekland 2000-09-27 rapporterades av Hudson (2010), men detta fynd har underkänts av den grekiska raritetskommittén (Nikos Probonas in litt.).

\begin{tabular}{|c|c|c|c|c|c|}
\hline Area, country & Site & Date (YMD) & RC treatment* & Sequenced & Reference \\
\hline Område, land & Lokal & Datum (ÅMD) & Rk-behandling* & Sekvenserad & Referens \\
\hline \multicolumn{6}{|l|}{ Fennoscandia } \\
\hline Sweden & Ottenby, Öland & 2003-05-29 & accepted & yes & Irwin \& Hellström 2007 \\
\hline Finland & Lågskär, Åland & $2012-05-20$ & accepted & no & Väisänen et al. 2015 \\
\hline Denmark & Blåvand, Jylland & $2015-05-27$ & pending & yes & this study \\
\hline \multicolumn{6}{|c|}{ Remaining NW Europe } \\
\hline Germany & Helgoland & $1867-10-11$ & accepted & no & Gätkhe 1900 \\
\hline UK & St Mary, Isles of Scilly & $1983-09-26$ & accepted & no & Hudson 2010 \\
\hline Faroe Islands & Nolsoy & $1997-06-08$ & accepted & yes & Sørensen \& Jensen 2001 \\
\hline UK & Foula, Shetland & 2014-05-31 & accepted & no & Pennington in litt. \\
\hline UK & Unst, Shetland & 2016-05-12 & accepted & yes & Pennington 2016 \\
\hline \multicolumn{6}{|l|}{ SE Europe } \\
\hline Greece** & Antikythira Island & $1998-09-18$ & accepted & no & Hellenic Rarities Committee 2006 \& 2009 \\
\hline Romania & Chituk & 2016-10-05 & pending & no & Milvus Group 2016 \\
\hline
\end{tabular}
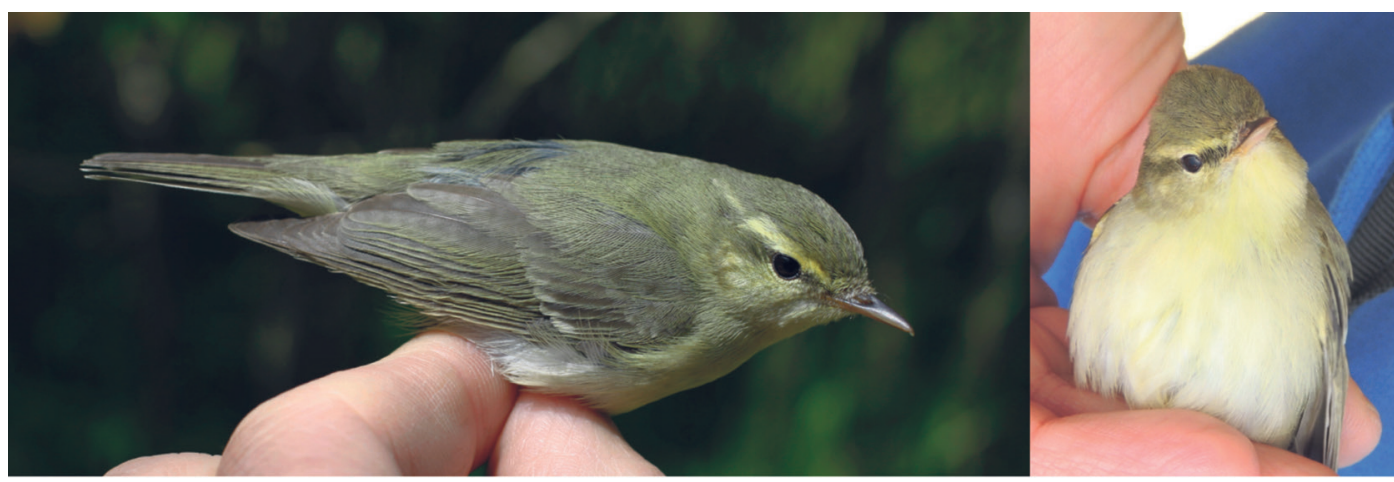

Figure 1. Green Warbler Phylloscopus nitidus, caught on 27 May 2015, in Blåvand, Denmark. Note rather green upperparts, one clearly visible wing-bar on the greater coverts, and yellowish breast, which are characters that distinguish it from Greenish Warbler Ph. trochiloides and Two-barred Warbler Ph. plumbeitarsus. Photos: Henrik Knudsen (left) and Morten Bentzon Hansen (right).

Kaukasisk lundsångare Phylloscopus nitidus, fångad 27 maj 2015 i Blåvand, Danmark. Notera tämligen grön översida, endast ett synligt vingband längs de större armtäckarna samt gultonat bröst, vilka är karaktärer som skiljer den från lundsångare Ph. trochiloides och sibirisk lundsångare Ph. plumbeitarsus. Foton: Henrik Knudsen (vänster) och Morten Bentzon Hansen (höger). 
immediately suspected of being a probable Green Warbler.

The bird was measured and photographed (Figure 1). The wing length (maximum chord; Svensson 1992) was recorded at $61.5 \mathrm{~mm}$, primary 3-4 formed the wing tip, and the tip of the second primary fell at the tip of primary 7. During the process, the bird shed two downs which were collected for DNA typing, as the species determination was not conclusive. After five hours, the bird was relocated and seen clearly in the field. The next day, however, the bird could not be found.

The colouration of the bird was quite different compared to a Greenish Warbler. The upperparts were bright green without the greyish wash, which is typical of Greenish Warbler. The supercilium was yellow, not white, as in Greenish Warbler. The throat and upper breast were yellow contrasting to the white lower breast and belly. The wing bar on the tip of the greater secondary coverts was prominent and broader compared to Greenish Warblers seen in the spring (Figure 1). In the hand, the size and shape of the bird was not perceived as different from Greenish Warbler, but on some photos the head looks larger and more robust than that of Greenish Warbler. The bird was not heard, but when a recording of Green Warbler song was played, the bird duly appeared. Regrettably, no recording of Greenish Warbler was played, so the potential response to that species is unknown.

\section{Methods}

The bases of the collected downs were cut off and digested for three hours at $56{ }^{\circ} \mathrm{C}$ in $100 \mu$ lysis buffer (0.1 M Tris, 0.005 EDTA, 0.2\% SDS, $0.2 \mathrm{M}$ $\mathrm{NaCl}, \mathrm{pH} 8.5)$ with $1.5 \mu \mathrm{l}$ proteinase $\mathrm{K}(10 \mathrm{mg} / \mathrm{ml})$ and then precipitated with ethanol and eluted in $20 \mu \mathrm{ldd} \mathrm{H}_{2} \mathrm{O}$. For typing of the mitochondrial cytochrome $b^{2}$ (cyt $\left.b\right)$ gene, we used the Qiagen Multiplex PCR Kit (Qiagen Inc.), with amplification reactions containing $5 \mu \mathrm{l}$ Qiagen Multiplex PCR Master Mix, $0.2 \mu \mathrm{l}$ each of $10 \mu \mathrm{M}$ primers ND5Syl (Stervander et al. 2015) and mtF-NP (Fregin et al. 2009), $2 \mu$ template DNA (non-diluted elution), and $2.6 \mu \mathrm{l}$ water. We ran the PCR reactions for activation at $95{ }^{\circ} \mathrm{C}$ for $15 \mathrm{~min}$. Then followed 40 three-step cycles with denaturation at $94{ }^{\circ} \mathrm{C}$ for $30 \mathrm{~s}$; annealing for 20 cycles in a touchdown profile decreasing by $0.5^{\circ} \mathrm{C}$ per cycle from $55^{\circ} \mathrm{C}$, followed by 20 cycles at $45^{\circ} \mathrm{C}$ for $90 \mathrm{~s}$; and extension at $72{ }^{\circ} \mathrm{C}$ for $90 \mathrm{~s}$. Finally, we allowed extension at $72{ }^{\circ} \mathrm{C}$ for $10 \mathrm{~min}$. PCR products were checked on a
$1 \%$ agarose gel, precipitated with $\mathrm{NH} 4 \mathrm{Ac}$ and ethanol, and then dissolved in $25 \mu \mathrm{l}$ water. We used $2 \mu \mathrm{l}$ for sequencing with the internal sequencing primer Cytb_seq_H15541 (Stervander et al.2015) with the BigDye sequencing kit (Applied Biosystems) in an ABI Prism 3100 capillary sequencer (Applied Biosystems).

The cyt $b$ sequence was manually inspected and edited in Geneious v. 10 (Biomatters). GenBank sequences of $>900 \mathrm{bp}$ were downloaded for all Phylloscopus/Seicercus/Abrornis (different genus names used for one monophyletic clade) and outgroups (Cettia/Horornis, Aegithalos, Acrocephalus, Cisticola, Sylvia), and aligned with the MAFFT v7.222 (Katoh et al. 2002) Geneious plugin. The 394 reference sequences included in this study are specified in Appendix 1.

Substitution models were evaluated with jModelTest v. 2.1.4 (Guindon \& Gascuel 2003, Darriba et al. 2012), selecting from 88 available models allowing for rate heterogeneity according to four gamma categories and for a proportion of invariable sites. Model selection was performed per the Bayesian Information Criterion (BIC; Schwarz 1978).

$\mathrm{Cyt} b$ gene trees were computed within a Bayesian inference (BI) framework with BEAST v. 2.4.4 (Bouckaert et al. 2014), using a Yule tree prior, and a strict molecular clock with a rate of 0.0105 substitution/site/lineage/million years, based on overall cyt $b$ substitution rates for a wide range of avian species (Weir \& Schluter 2008). We applied four discrete categories over the gamma distribution, and estimated the frequency of invariant sites as well as the base frequencies. We performed two replicate runs, and sampled trees every 1,000 generations, over 30 million generations, of which the first $10 \%$ were discarded as burn-in. The results were inspected using Tracer v. 1.6 (Rambaut et al. 2013), ensuring stationarity and effective sample sizes (ESS) of $>200$, and ascertaining congruence between replicate runs.

The maximum clade credibility tree was calculated with TreeAnnotator (Bouckaert et al. 2014), using average node heights, and excluding $10 \%$ as burn-in. This tree was visualized and annotated in FigTree v.1.4.3 (Rambaut 2016) and Mega 7 (Kumar et al. 2016).

\section{Results}

The trimmed sequence from the Blåvand bird was $681 \mathrm{bp}$, of which $633 \mathrm{bp}$ covered parts of the cytb gene from its start, preceded by the last $40 \mathrm{bp}$ of the ND5 gene and 8 intergenic bp. The cyt $b$ sequence 


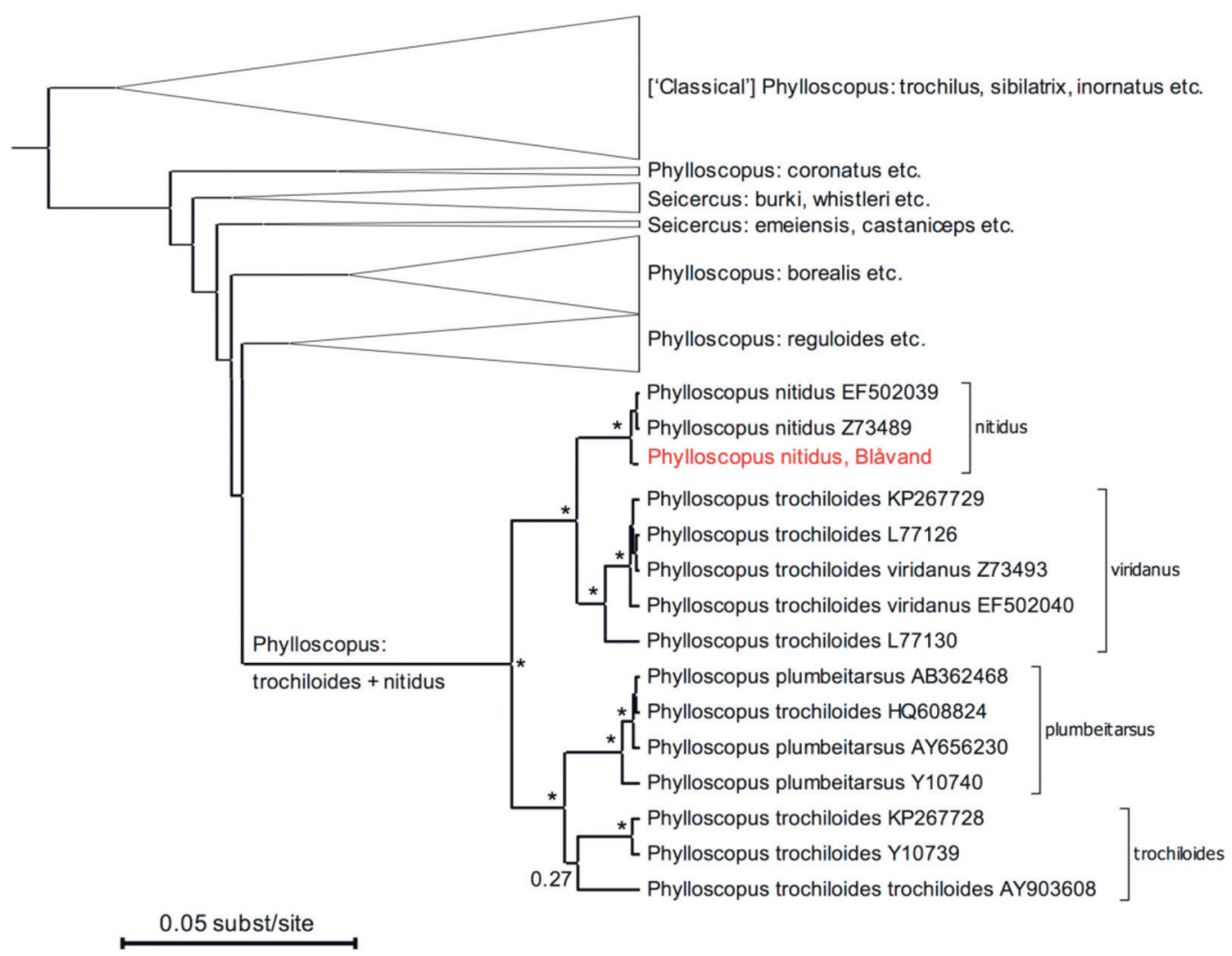

Figure 2. Phylogeny of Seicercus and Phylloscopus warblers, based on Baeysian inference of 394 cytochrome $b$ sequences, which places the Blåvand bird (highlighted in red font) in the Green Warbler Ph. nitidus clade with maximal support. Sequences from the complex containing Green Warbler and Greenish Warbler Ph. trochiloides are shown with their taxon names as submitted to Genbank, with bracket annotations stating which clade they correspond to. Posterior probability (PP; $0.0-1.0)$ is indicated for nodes in this clade: $*$ indicates $\mathrm{PP}=1.0, \mathrm{PP}$ otherwise stated with a number at the node. All other clades have been collapsed, with the height of the triangle corresponding to number of sequences, and labels including taxa representative of the clade. For a full list of included taxa, and all Genbank accession numbers, see Appendix 1. Note that the traditional use of the genus names Seicercus and Phylloscopus does not reflect monophyletic groups. The outgroups have been removed for clarity.

Fylogeni över sångare inom släktena Seicercus och Phylloscopus, baserad på bayesiansk inferens av 394 cytokrom b-sekvenser, vilken placerar fågeln från Blåvand (markerad med röd text) $i$ kladen med kaukasisk lundsångare Ph. nitidus med maximalt statistiskt stöd. Sekvenser från komplexet som omfattar kaukasisk lundsångare och lundsångare Ph. trochiloides visas namngivna såsom de skickats in till Genbank, med klamrar som indikerar vilken klad de tillhör. Posteriorisannolikhet (PP; 0,0-1,0) visas för noder inom denna klad: * indikerar $P P=1,0, P P$ visas annars med en siffra vid noden. Alla andra klader har minimerats och triangelns höjd motsvarar antalet sekvenser som ingår $i$ kladen. Representativa taxa har listats bredvid triangeln. För den fulla listan över inkluderade taxa, samt deras Genbank-nummer, se Appendix 1. Notera att den traditionella användningen av släktesnamnen Seicercus och Phylloscopus inte motsvarar monofyletiska grupper. Utgrupperna har uteslutits från figuren för tydlighet.

aligned with no gaps to cyt $b$ sequences of related species, and is available at Genbank with the accession number MF188243.

The best estimated substitution model was HKY (Hasegawa et al. 1985) with rate variation following a discrete gamma distribution with four rate categories $(\mathrm{G})$ and with an estimated fraction of invariant sites (I).
The computed cyt $b$ phylogeny groups the Blåvand bird with full statistical support (posterior probability 1.0) together with two sequences of Green Warblers in a nitidus clade, that is sister to the viridanus clade (Figure 2). Those two clades, in turn, make up as a sister clade to the clade containing the sisters trochiloides and plumbeitarsus (Figure 2). 


\section{Discussion}

Green Warbler may be an overlooked species in western and northern Europe because it is rather similar to Greenish Warbler. Even with good views the two species may be difficult to distinguish, and good views may be hard to achieve owing to the restless nature of the species and their habit of foraging high above the ground. However, very few Green Warblers have been caught in Europe compared to the number of Greenish Warblers, so the species is probably a quite rare vagrant in Europe.

The phylogenetic analysis clearly confirms that the Blåvand bird is a Green Warbler (Figure 2). It further highlights the special case that the Green/ Greenish/Two-barred Warbler complex constitutes. Under a phylogenetic species concept, a species must be monophyletic, i.e. all of its subspecies/ populations/individuals must be most closely related to each other, and together form a clade that contains no other taxa. However, the cyt $b$ phylogeny shows that the two Greenish Warbler clades (trochiloides and viridanus; Figure 2) are not each other's closest relatives, but instead make up sister clades with Two-barred Warbler (plumbeitarsus) and Green Warbler (nitidus), respectively. Thus, judging from the cyt $b$ phylogeny alone, Greenish Warbler is paraphyletic, and either all taxa within the complex represent one species, or all should be regarded separate species.

However, while mitochondrial markers such as cyt $b$ are appropriate for taxon identification, taxonomic conclusions should not rest solely on such information. Mitochondrial genetic markers differ from nuclear genetic markers because of a faster molecular substitution rate, and because of maternal inheritance. When populations diverge, mitochondrial and nuclear genetic markers may leave different phylogenetic signatures because they sort at different rates. Also, if diverged populations later come into secondary contact, mitochondrial and nuclear genetic markers will be differentially prone to introgression depending on the stage of divergence (Rheindt \& Edwards 2011). For that reason, interpretations of phylogenetic relationship should best be based on multi-locus analyses including nuclear genetic markers (e.g. Rheindt \& Edwards 2011, Stervander et al. 2015).

Further, the Greenish/Green/Two-barred Warbler clade is unusually well studied, and illustrates some of the problems highlighted above. The Greenish and Two-barred Warbler occur in a broken ring around the Tibetan plateau. The Two-barred Warbler occupies the north-eastern part of the ring, and is isolated with a break in the ring to the south, while it meets the Greenish Warbler in a contact zone to the west. Despite the contact, the two species remain their integrity. The distribution of the Greenish warbler continues counter-clockwise around the Tibetan plateau until the gap the occurs east of the plateau, before reaching the distribution of the Two-barred Warbler. When Irwin at el. (2001) analysed divergence in song and mitochondrial DNA along the broken ring, they concluded that the complex had likely evolved along the ring. Neighbouring populations were only slightly differentiated, but the differentiation progressed on a gradient along the ring, and reproductive isolation was complete in the two end-points, represented by the Siberian populations of Greenish and Two-barred Warbler. However, when Alcaide et al. (2014) made use of "next generation sequencing" of massive amounts of nuclear DNA, they revealed that this interpretation was not correct. Instead they uncovered that there have been multiple historical breaks in gene flow, when populations have been isolated at several locations along the ring. Nevertheless, while this species complex may not represent a rare case of a "ring species", it illustrates a complex evolutionary history resulting in varying levels of genetic differentiation between subspecies and species.

Finally, it is worth to mention that the two genera Phylloscopus and Seicercus, which presently constitute the family Phylloscopidae, are paraphyletic (Figure 2; Olsson et al. 2004). The family will therefore likely be split into multiple genera that better reflect their evolutionary relationships (P. Alström pers. comm., Gill \& Donsker 2017).

\section{Acknowledgements}

Thanks to the late Martin Garner, Jochen Dierschke, Lars Svensson, Arnoud B. van den Berg, and Simon Sigaard Christiansen for initial comments about the identification of the bird. Sören Svensson and an anonymous referee gave valuable comments that improved the manuscript.

\section{Author contributions}

H. K. trapped the bird and wrote the description; A. B. K. researched previous records and contributed to the manuscript; M. S. performed the lab work and the phylogenetic analyses, and wrote the manuscript. 


\section{References}

Alcaide, M., Scordato, E. S., Price, T. D. \& Irwin, D. E. 2014. Genomic divergence in a ring species complex. Nature 511: 83-5.

BOU (British Ornithologists' Union) 2009. Records Committee: 37th Report. Ibis 151: 224-230.

Bouckaert, R., Heled, J., Kühnert, D., Vaughan, T., Wu, C-H., Xie, D., Suchard, MA., Rambaut, A. \& Drummond, A. J. 2014. BEAST 2: A Software Platform for Bayesian Evolutionary Analysis. PLoS Computational Biology 10(4): e1003537.

Clements, J. F., Schulenberg, T. S., Iliff, M. J., Sullivan, B. L. \& Wood C. L. 2009. The eBird/Clements checklist of birds of the world: v2009. URL: http://www.birds.cornell.edu/ clementschecklist/updateindex/dec09overview/

Clements, J. F., Schulenberg, T. S., Iliff, M. J., Sullivan, B. L., Wood C. L., Fredericks, T. A. \& Roberson, D. 2014. The eBird/Clements checklist of birds of the world: v2014. URL: http://www.birds.cornell.edu/clementschecklist/2014overview/

Darriba, D., Taboada, G.L., Doallo, R. \& Posada, D. 2012. jModelTest 2: more models, new heuristics and parallel computing. Nature Methods 9: 772-772.

Fregin, S., Haase, M., Olsson, U. \& Alström, P. 2009. Multilocus phylogeny of the family Acrocephalidae (Aves: Passeriformes) - the traditional taxonomy overthrown. Molecular Phylogenetics and Evolution 52: 866-878.

Gill, F. \& Donsker, D. (eds). 2017. IOC World Bird List (v 7.2). DOI: 10.14344/IOC.ML.7.2.

Gill, F. \& Wright, M. (eds). 2006. Birds of the World: Recommended English Names. Christopher Helm, London.

Guindon, S. \& Gascuel, O. 2003. A simple, fast, and accurate algorithm to estimate large phylogenies by maximum likelihood. Systematic Biology 52: 696-704.

Gätke, H. 1900. Die Vogelwarte Helgoland. 2. Aufl. Joh. Heinr. Meyer, Braunschweig.

Hasegawa, M., Kishino, H. \& Yano, T.A. 1985. Dating of the Human Ape Splitting by a Molecular Clock of Mitochondrial-DNA. Journal of Molecular Evolution 22: 160-174.

Hellenic Rarities Committee 2006. Annual Report - 2005. URL: http://rarities.ornithologiki.gr/gr/eaop/annual_reports.htm.

Hellenic Rarities Committee 2009. Annual Report - 2008. URL: http://rarities.ornithologiki.gr/gr/eaop/annual_reports.htm.

Hudson, N. 2010. Green Warbler on Scilly: new to Britain. British Birds 103: 93-99.

del Hoyo, J., Elliott, A., Christie, D. A. (eds.) 2006. Handbook of the Birds of the World. Vol. 11. Old World Flycatchers to Old World Warblers. Lynx Edicions, Barcelona.

IRDC 2016. Israel Rarities and Distribution Committee. URL: http://www.israbirding.com/irdc/bulletins/bulletin_10/.

Irwin, D. E., Bensch, S. \& Price, T. D. 2001. Speciation in a ring. Nature 409: 333-337.

Irwin, D. E. \& Hellström, M. 2007. Green Warbler Phylloscopus (trochiloides) nitidus recorded at Ottenby, Öland: a first record for Scandinavia. Ornis Svecica 17: 75-80.

Katoh, K., Misawa, K., Kuma, K. \& Miyata, T. 2002. MAFFT: a novel method for rapid multiple sequence alignment based on fast Fourier transform. Nucleic Acids Research 30: 3059-3066.
Knox, A. G., Collinson, J. M., Parkin, D. T., Sangster, G. \& Svensson, L. 2008. Taxonomic recommendations for British birds: Fifth report. Ibis 150: 833-835.

Kumar, S., Stecher, G. \& Tamura, K. 2016. MEGA7: Molecular Evolutionary Genetics Analysis version 7.0 for bigger datasets. Molecular Biology and Evolution 33(7): 1870-1874.

Milvus Group 2016. URL: http://milvus.ro/en/12-146-depasari-inelate-in-2016-pe-grindul-chituc/8640 (accessed on 23 November 2016).

Olsson U., Alström, P. \& Sundberg, P. 2004. Non-monophyly of the avian genus Seicercus (Aves: Sylviidae) revealed by mitochondrial DNA. Zoologica Scripta 33(6): 501-510.

Pennington, M. 2016. Green Warbler at Baltasound, Shetland, 12-15 May 2016 - first record for Scotland. Scottish Birds 36: 264-268.

Rambaut, A., Suchard, M.A. \& Drummond, A.J. 2013. Tracer v. 1.6, available from http://tree.bio.ed.ac.uk/software/ tracer/.

Rambaut, A. 2016. FigTree v. 1.4.3, available from http://tree. bio.ed.ac.uk/software/figtree/.

Rheindt, F. E. \& Edwards, S.V. 2011. Genetic introgression: an integral but neglected component of speciation in birds. Auk 128(4): 620-632.

Schwarz, G. 1978. Estimating Dimension of a Model. Annals of Statistics 6: 461-464.

Slack, R. 2009. Rare Birds Where and When. An Analysis of Status and Distribution in Britain and Ireland. Volume 1. Rare Bird Books, York.

Stervander, M., Illera, J. C., Kvist, L., Barbosa, P., Keehnen, N. P., Pruisscher, P., Bensch, S. \& Hansson, B. 2015. Disentangling the complex evolutionary history of the Western Palearctic blue tits (Cyanistes spp.) - phylogenomic analyses suggest radiation by multiple colonisation events and subsequent isolation. Molecular Ecology 24: 24772494.

Svensson, L. 1992. Identification Guide to European Passerines. 4th revised and enlarged edition. L. Svensson, Stockholm.

Sørensen, S. \& Jensen, J. K. 2001. Sjældne fugle på Færøerne i 1997-2000. Rapport nr. 30 fra Sjældenhedsudvalget. DOFT 95(2): 44-50.

Väisänen, R., Huhtinen, H. Lampila P., Lehikoinen, A., Lehikoinen, P., Normaja, J. \& Velmala, W. 2015: Rariteettikomitean hyväksymät vuoden 2014 harvinaisuushavainnot (Summary: Rare birds in Finland in 2014.) Linnut - vuosikirja 2014: 78-93.

Weir, J. T. \& Schluter, D. 2008. Calibrating the avian molecular clock. Molecular Ecology 17: 2321-2328.

\section{Sammanfattning}

Den 27 maj 2016 fångades och ringmärktes en lundsångarliknande fågel vid Blåvands fågelstation, som är belägen vid Danmarks västligaste punkt. Datumet är tidigare än tyngdpunkten för lundsångarfynd vid Blåvand, och fågeln avvek något $\mathrm{i}$ dräkt från lundsångare Phylloscopus trochiloides. Redan vid fångsten misstänktes att fågeln var en kaukasisk lundsångare $P h$. nitidus, men dessa är 
svåra att säkert bestämma enbart baserat på morfologi. Färgsättningen skilde sig jämfört med lundsångare på så sätt att den aktuella fågeln hade en tydligare grön ovansida, utan gråton (Figur 1). Dessutom var ögonbrynsstrecket gult snarare än vitt och strupe samt övre bröst var gula, tydligt kontrasterande mot vitt nedre bröst och mage (Figur 1). Vingbandet, format av de större armtäckarnas ljusa spetsar, var bredare och tydligare jämfört med lundsångare (Figur 1).

Vid hanteringen tappade fågeln två dun, vilka användes för utvinning av DNA. Med hjälp av PCR mångfaldigades en DNA-sekvens från den maternellt nedärvda mitokondriegenen cytokrom $b$. En fylogenetisk analys av denna sekvens, tillsammans med alla publikt tillgängliga cytokrom $b$-sekvenser från fåglar inom släktena Phylloscopus/Seicercus/ Abrornis (olika släktesnamn som används för en och samma monofyletiska klad) samt utgrupper (taxa från släktena Cettia/Horornis, Aegithalos, Acrocephalus, Cisticola och Sylvia) bekräftar att fågeln var en kaukasisk lundsångare (Figur 2).

Det fylogenetiska trädet (Figur 2) belyser ett par speciella förhållanden. Phylloscopus och Seicercus är båda parafyletiska släkten, dvs. de omfattar inte bara taxa som är närmast besläktade med varandra och bildar obrutna monofyletiska grupper. I stället förekommer arter som kallas Phylloscopus och Seicercus på olika ställen i fylogenin (Figur 2). Därmed är en taxonomisk revision att vänta för hela familjen Phylloscopidae. Dessutom uppvisar lundsångarkomplexet, med lundsångare, kaukasisk lundsångare och sibirisk lundsångare $P h$. plumbeitarsus, ett osedvanligt komplicerat inbördes förhållande. Medan den kaukasiska lundsångaren har ett isolerat utbredningsområde huvudsakligen i Kaukasus och norra Iran återfinns lundsångaren och den sibiriska lundsångaren öster därom $\mathrm{i}$ en bruten ring kring Tibetanska högplatån. De två arterna möts, utan att blandas, i östra Sibirien, medan urskiljbara populationer av lundsångaren förekommer med en kontinuerlig utbredning motsols till platåns östra sida. Tidigare, med stöd av analyser av mitokondriellt DNA och sång, har detta komplex tolkats som representanter för en s.k. ringart, där en art spridits och differentierats kontinuerligt längs en ring, så att ändarna, där de möts, är fullgoda arter, medan populationerna dem emellan endast skiljer sig gradvis. Nyare studier, baserade på analyser av stora delar av cellkärnans arvsmassa hos flera av arterna, visar att det inte alls handlar om en ringart, utan att flera av populationerna runt ringen tidvis har varit isolerade. Hybridisering och introgression av genetiskt material mellan arterna har skapat ett komplext fylogenetiskt mönster, där det mitokondriella fylogenetiska trädet inte speglar artträdet (Figur 2).

Fyndet i Blåvand utgör Danmarks första fynd av kaukasisk lundsångare, Fennoskandias tredje - efter fynd på Öland den 29 maj 2003 och Åland den 20 maj 2012 - och Europas åttonde fynd (Tabell 1) utanför ett begränsat och perifert europeiskt häckningsområde i södra Ryssland och norra Georgien. 


\section{Appendix 1}

Taxa and GenBank accession number for cytochrome $b$ sequences included in the phylogenetic analysis. Taxa och GenBank-nummer för de cytokrom b-sekvenser som inkluderats i den fylogenetiska analysen.

\begin{tabular}{|c|c|c|c|}
\hline $\begin{array}{l}\text { Taxon } \\
\text { Taxon }\end{array}$ & $\begin{array}{l}\text { Accession no } \\
\text { Genbank-nr }\end{array}$ & $\begin{array}{l}\text { Taxon } \\
\text { Taxon }\end{array}$ & $\begin{array}{l}\text { Accession no } \\
\text { Genbank-nr }\end{array}$ \\
\hline Abrornis chloronotus & KJ456391 & Phylloscopus reguloides reguloides & AY656235 \\
\hline Abrornis chloronotus simlaensis & DQ008504 & Phylloscopus reguloides reguloides & AY656236 \\
\hline Abrornis humei & KJ456394 & Phylloscopus reguloides reguloides & AY656237 \\
\hline Abrornis humei humei & Z73488 & Phylloscopus reguloides reguloides & AY656238 \\
\hline Abrornis inornata & AY635054 & Phylloscopus reguloides ticehursti & AY656205 \\
\hline Abrornis inornata & DQ792799 & Phylloscopus reguloides ticehursti & AY656206 \\
\hline Abrornis inornata & DQ792800 & Phylloscopus reguloides ticehursti & AY656207 \\
\hline Abrornis inornata & KF742677 & Phylloscopus reguloides ticehursti & AY656233 \\
\hline Abrornis inornata & L77135 & Phylloscopus reguloides ticehursti & AY656234 \\
\hline Abrornis inornata & NC_024726 & Phylloscopus reguloides ticehursti & AY656242 \\
\hline Abrornis inornata & Y10734 & Phylloscopus reguloides ticehursti & AY656243 \\
\hline Abrornis maculipennis & HQ608828 & Phylloscopus ricketti & AY656239 \\
\hline Abrornis maculipennis & KJ456395 & Phylloscopus ricketti & GU045622 \\
\hline Abrornis maculipennis & Y10731 & Phylloscopus ricketti & GU045623 \\
\hline Abrornis maculipennis maculipennis & AY635055 & Phylloscopus ricketti & GU045624 \\
\hline Abrornis proregulus & AY635058 & Phylloscopus ricketti & GU045625 \\
\hline Abrornis proregulus & DQ792796 & Phylloscopus ruficapilla minullus & AY635060 \\
\hline Abrornis proregulus & DQ792797 & Phylloscopus sarasinorum sarasinorum & AY656240 \\
\hline Abrornis proregulus & DQ792798 & Phylloscopus schwarzi & AY635061 \\
\hline Abrornis proregulus & HQ608830 & Phylloscopus schwarzi & HQ608825 \\
\hline Abrornis proregulus & L77134 & Phylloscopus schwarzi & Y10728 \\
\hline Abrornis proregulus & Y10733 & Phylloscopus sibilatrix & AY944178 \\
\hline Abrornis yunnanensis & HQ608833 & Phylloscopus sibilatrix & L77123 \\
\hline Acrocephalus schoenobaenus & 273475 & Phylloscopus sibilatrix & 273491 \\
\hline Acrocephalus scirpaceus scirpaceus & Z73483 & Phylloscopus sindianus & L77136 \\
\hline Aegithalos concinnus & JX398849 & Phylloscopus sindianus lorenzii & HQ706180 \\
\hline Aegithalos concinnus concinnus & KF951091 & Phylloscopus sindianus lorenzii & 273478 \\
\hline Cettia fortipes & L77122 & Phylloscopus subviridis & KJ456398 \\
\hline Cisticola juncidis & 273474 & Phylloscopus trivirgatus & L77145 \\
\hline Horornis diphone & AB159194 & Phylloscopus trivirgatus trivirgatus & AY656244 \\
\hline Horornis diphone & AB159195 & Phylloscopus trochiloides & HQ608824 \\
\hline Horornis diphone & AB159196 & Phylloscopus trochiloides & KP267728 \\
\hline Horornis diphone & AB159197 & Phylloscopus trochiloides & KP267729 \\
\hline Horornis diphone & AB159198 & Phylloscopus trochiloides & L77126 \\
\hline Horornis diphone & AB694915 & Phylloscopus trochiloides & L77130 \\
\hline Horornis diphone & AB694916 & Phylloscopus trochiloides & Y10739 \\
\hline Horornis diphone & HQ608838 & Phylloscopus trochiloides trochiloides & AY903608 \\
\hline Horornis seebohmi & AB281094 & Phylloscopus trochiloides viridanus & EF502040 \\
\hline Horornis seebohmi & AB281095 & Phylloscopus trochiloides viridanus & Z73493 \\
\hline Horornis seebohmi & AB281096 & Phylloscopus trochilus & AJ004326 \\
\hline Phylloscopus affinis & DQ008503 & Phylloscopus trochilus & AY944177 \\
\hline Phylloscopus affinis & KJ456389 & Phylloscopus trochilus & DQ174582 \\
\hline Phylloscopus affinis & L77128 & Phylloscopus trochilus & DQ174583 \\
\hline Phylloscopus affinis & Y10730 & Phylloscopus trochilus & DQ174584 \\
\hline Phylloscopus amoenus & AY887676 & Phylloscopus trochilus & DQ174585 \\
\hline Phylloscopus armandii & HQ608831 & Phylloscopus trochilus & DQ174586 \\
\hline Phylloscopus bonelli & AY944179 & Phylloscopus trochilus & DQ174587 \\
\hline Phylloscopus bonelli & L77127 & Phylloscopus trochilus & DQ174588 \\
\hline Phylloscopus bonelli bonelli & Z73485 & Phylloscopus trochilus & DQ174589 \\
\hline Phylloscopus bonelli bonelli & Z73486 & Phylloscopus trochilus & DQ174590 \\
\hline
\end{tabular}


Phylloscopus borealoides

Phylloscopus borealoides

Phylloscopus borealoides

Phylloscopus brehmi

Phylloscopus brehmi

Phylloscopus calciatilis

Phylloscopus calciatilis

Phylloscopus calciatilis

Phylloscopus calciatilis

Phylloscopus calciatilis

Phylloscopus calciatilis

Phylloscopus calciatilis

Phylloscopus calciatilis

Phylloscopus calciatilis $\mathrm{x}$ ricketti

Phylloscopus canariensis

Phylloscopus cantator

Phylloscopus cantator cantator

Phylloscopus cebuensis

Phylloscopus cebuensis

Phylloscopus claudiae

Phylloscopus claudiae

Phylloscopus claudiae

Phylloscopus claudiae

Phylloscopus claudiae

Phylloscopus collybita

Phylloscopus collybita

Phylloscopus collybita

Phylloscopus collybita abietinus

Phylloscopus collybita abietinus

Phylloscopus collybita abietinus

Phylloscopus collybita abietinus

Phylloscopus collybita abietinus

Phylloscopus collybita abietinus

Phylloscopus collybita abietinus

Phylloscopus collybita brevirostris

Phylloscopus collybita caucasicus

Phylloscopus collybita collybita

Phylloscopus collybita menzbieri

Phylloscopus collybita tristis

Phylloscopus collybita tristis

Phylloscopus collybita tristis

Phylloscopus collybita tristis

Phylloscopus coronatus

Phylloscopus coronatus

Phylloscopus coronatus

Phylloscopus coronatus

Phylloscopus davisoni

Phylloscopus davisoni disturbans

Phylloscopus davisoni klossi

Phylloscopus emeiensis

Phylloscopus fuligiventer

Phylloscopus fuscatus
AB362459

AB362467

AY887677

AJ004325

273476

GU045613

GU045614

GU045615

GU045616

GU045617

GU045618

GU045619

GU045620

GU045621

Z73477

KJ456390

AY656208

JN827147

L77144

AY656209

AY656210

AY656211

AY656212

AY656213

AJ004324

HQ608821

L77125

DQ174604

DQ174605

DQ174606

DQ174607

DQ174608

HQ121526

Z73479

Z73480

Z73481

273487

AF136374

HF562844

HF562845

HF562846

273482

AB362460

AY635053

HQ608834

L77139

AY656214

AY656217

AY656215

AY656218

KJ456392

DQ119527
Phylloscopus trochilus

Phylloscopus trochilus

Phylloscopus trochilus

DQ174591

DQ174592

Phylloscopus trochilus

DQ174593

DQ174594

Phylloscopus trochilus

DQ174595

Phylloscopus trochilus

DQ174596

Phylloscopus trochilus

DQ174597

Phylloscopus trochilus

Phylloscopus trochilus

DQ174598

JX869889

Phylloscopus trochilus

L77124

Phylloscopus trochilus trochilus

DQ673875

Z73492

AY887679

Phylloscopus tytleri

$\mathrm{L} 77132$

KJ456460

AY635066

AY635069

AY635070

AY635071

AY635063

HQ608832

L77138

L77143

AB362438

AB362439

AB362440

AB362441

AB362442

AB362443

AB362444

AB362445

AB362446

AB362462

AB530997

AB530998

AB530999

AB531000

AB531001

AB531002

AB531003

AY635052

HQ243658

HQ243659

HQ243660

KP245888

Z73484

AB362435

AB362436

AB362437

AB362461

AY635064

AY635065 
Phylloscopus fuscatus

Phylloscopus fuscatus

Phylloscopus fuscatus

Phylloscopus fuscatus

Phylloscopus fuscatus

Phylloscopus fuscatus

Phylloscopus fuscatus

Phylloscopus goodsoni fokiensis

Phylloscopus goodsoni fokiensis

Phylloscopus goodsoni fokiensis

Phylloscopus goodsoni fokiensis

Phylloscopus goodsoni fokiensis

Phylloscopus goodsoni goodsoni

Phylloscopus goodsoni goodsoni

Phylloscopus goodsoni goodsoni

Phylloscopus goodsoni goodsoni

Phylloscopus griseolus

Phylloscopus hainanus

Phylloscopus magnirostris

Phylloscopus magnirostris

Phylloscopus magnirostris

Phylloscopus magnirostris

Phylloscopus magnirostris

Phylloscopus nigrorum benguetensis

Phylloscopus nitidus

Phylloscopus nitidus

Phylloscopus occipitalis

Phylloscopus occipitalis

Phylloscopus occipitalis

Phylloscopus occipitalis

Phylloscopus occisinensis

Phylloscopus ogilviegranti ogilviegranti

Phylloscopus orientalis

Phylloscopus orientalis

Phylloscopus plumbeitarsus

Phylloscopus plumbeitarsus

Phylloscopus plumbeitarsus

Phylloscopus poliocephalus giulianetti

Phylloscopus pulcher

Phylloscopus pulcher

Phylloscopus pulcher

Phylloscopus pulcher

Phylloscopus pulcher

Phylloscopus pulcher

Phylloscopus pulcher

Phylloscopus pulcher

Phylloscopus pulcher

Phylloscopus pulcher

Phylloscopus pulcher

Phylloscopus pulcher

Phylloscopus pulcher

Phylloscopus pulcher
DQ174599

DQ174600

DQ174601

DQ174602

DQ174603

HQ608823

Y10729

AY656219

AY656220

AY656221

AY656222

AY656223

AY656225

AY656226

AY656227

AY656228

KJ456393

AY656229

AY635056

AY887681

HQ608822

L77129

Y10737

AY656204

EF502039

Z73489

AY635057

EU372678

L77131

Y10735

HQ608829

AY656216

AY887678

Z73490

AB362468

AY656230

Y10740

AY656224

HQ608826

KJ456396

KJ567540

KJ567541

KJ567542

KJ567543

KJ567544

KJ567545

KJ567546

KJ567547

KJ567548

KJ567549

KJ567550

KJ567551
Seicercus burkii

Seicercus castaniceps

Seicercus castaniceps

Seicercus castaniceps

Seicercus castaniceps castaniceps

Seicercus examinandus

Seicercus examinandus

Seicercus examinandus

Seicercus examinandus

Seicercus examinandus

Seicercus examinandus

Seicercus examinandus

Seicercus examinandus

Seicercus examinandus

Seicercus examinandus

Seicercus examinandus

Seicercus examinandus

Seicercus examinandus

Seicercus examinandus

Seicercus examinandus

Seicercus examinandus

Seicercus examinandus

Seicercus examinandus

Seicercus examinandus

Seicercus examinandus

Seicercus examinandus

Seicercus examinandus

Seicercus examinandus

Seicercus examinandus

Seicercus examinandus

Seicercus examinandus

Seicercus examinandus

Seicercus examinandus

Seicercus examinandus

Seicercus examinandus

Seicercus examinandus

Seicercus examinandus

Seicercus grammiceps grammiceps

Seicercus ijimae

Seicercus ijimae

Seicercus montis montis

Seicercus omeiensis

Seicercus poliogenys

Seicercus poliogenys

Seicercus poliogenys

Seicercus poliogenys

Seicercus soror

Seicercus soror

Seicercus soror

Seicercus tenellipes

Seicercus tenellipes

Seicercus tenellipes
HQ608856

AY887680

HQ608857

KJ456461

AY635067

AB362424

AB362425

AB362426

AB362427

AB362428

AB362429

AB362430

AB362431

AB362432

AB362433

AB362434

AB362463

AB362464

KP245873

KP245874

KP245875

KP245876

KP245877

KP245878

KP245879

KP245880

KP245881

KP245882

KP245883

KP245884

KP245885

KP245886

KP245887

KP245895

KP245896

KP245897

KP245898

AY635068

L77141

Y10741

AY635073

AY635078

AY635079

AY635080

AY635081

KJ456462

AY635082

AY635083

KM875497

AY903607

L77140

Y10738 
Phylloscopus pulcher

Phylloscopus pulcher

Phylloscopus pulcher

Phylloscopus pulcher

Phylloscopus pulcher

Phylloscopus pulcher

Phylloscopus pulcher

Phylloscopus pulcher

Phylloscopus pulcher

Phylloscopus pulcher

Phylloscopus pulcher

Phylloscopus pulcher

Phylloscopus pulcher

Phylloscopus pulcher

Phylloscopus pulcher

Phylloscopus pulcher

Phylloscopus pulcher

Phylloscopus pulcher

Phylloscopus pulcher

Phylloscopus pulcher

Phylloscopus pulcher

Phylloscopus pulcher

Phylloscopus pulcher

Phylloscopus pulcher

Phylloscopus pulcher

Phylloscopus pulcher

Phylloscopus pulcher

Phylloscopus pulcher

Phylloscopus pulcher

Phylloscopus pulcher

Phylloscopus pulcher

Phylloscopus pulcher

Phylloscopus pulcher

Phylloscopus pulcher

Phylloscopus pulcher

Phylloscopus pulcher

Phylloscopus pulcher

Phylloscopus pulcher

Phylloscopus pulcher

Phylloscopus pulcher

Phylloscopus pulcher

Phylloscopus pulcher

Phylloscopus pulcher

Phylloscopus pulcher

Phylloscopus pulcher pulcher

Phylloscopus reguloides

Phylloscopus reguloides

Phylloscopus reguloides

Phylloscopus reguloides

Phylloscopus reguloides

Phylloscopus reguloides assamensis

Phylloscopus reguloides assamensis
KJ567552

KJ567553

KJ567554

KJ567555

KJ567556

KJ567557

KJ567558

KJ567559

KJ567560

KJ567561

KJ567562

KJ567563

KJ567564

KJ567565

KJ567566

KJ567567

KJ567568

KJ567569

KJ567570

KJ567571

KJ567572

KJ567573

KJ567574

KJ567575

KJ567576

KJ567577

KJ567579

KJ567580

KJ567581

KJ567582

KJ567583

KJ567584

KJ567585

KJ567586

KJ567587

KJ567588

KJ567589

KJ567590

KJ567592

KJ567594

KJ567595

KJ567596

L77133

Y10732

AY635059

HQ608827

KJ456397

KM248527

KM248529

Y10736

AY656231

AY656232
Seicercus tephrocephalus

Seicercus tephrocephalus

AY635084

Seicercus tephrocephalus

AY635085

Seicercus valentini latouchei

AY635062

AY635072

AY635086

AY635088

AY635087

AY635089

KJ456463

AY635074

AY635076

AY635075

AY635077

AY635090

AB362447

AB362448

AB362449

AB362450

AB362451

AB362452

AB362453

AB362454

AB362455

AB362456

AB362457

AB362458

AB362465

AB362466

AY656246

Seicercus xanthoschistos tephrodiras

AY635091

Sylvia atricapilla atricapilla

Z73494

Sylvia melanocephala

L77121 